\title{
Optimization of L-asparaginase Production from Some Filamentous Fungi with Potential Pharmaceutical Properties
}

\author{
Dalia I. Ali, Salama A. Ouf, Mohamed Eweis and Dina M. Soliman \\ Botany and Microbiology Department, Faculty of Science, Cairo University, Giza, \\ Cairo, Egypt.
}

\begin{abstract}
$\mathbf{O}$ NE HUNDRED and forty three isolates related to 16 fungal species were recovered from garden soil and indoor air of the medical chambers of Tumor Institute, Kasr El Ainy, Egypt. Quantitative L-asparaginase assay for isolated species was determined by Nesslerization. The fungal isolates exhibited different L-asparaginase activities. Aspergillus sydowii and Fusarium oxysporum showed the highest L-asparaginase activity where the activity reached 3.98 and $3.91 \mathrm{U} / \mathrm{ml}$ in the assay mixture after $48 \mathrm{~h}$ incubation period, respectively. The identification of $A$. sydowii and $F$. oxysporum was confirmed molecularly using Internal Transcribed Spacer Regions sequences. The optimization of the cultural conditions for the production of L-asparaginase was performed by using Taguchi design. Eight component factors of a modified medium were evaluated in influencing L-asparaginase yield. The highest L-asparagenolytic activity was achieved in culture media containing $1 \% \mathrm{~L}$-asparagine, $0.2 \%$ glucose, $0.1 \% \mathrm{KH}_{2} \mathrm{PO}_{4}, 0.025 \% \mathrm{KCl}, 0.052 \% \mathrm{MgSO}_{4} .7 \mathrm{H}_{2} \mathrm{O}$, pH 5.0 and incubation at $40^{\circ} \mathrm{C}$ in a rotatory incubator (100 rpm) for 5 days, where enzyme activities of 146 and $143 \mathrm{U} / \mathrm{ml}$ were measured for $A$. sydowii and $F$. oxysporum, respectively. Anti-leukemic activity of the crude enzyme of either A. sydowii or F. oxysporum against murine RAW264.7 leukemia cells line using MTT viability assay with $\mathrm{IC}_{50}$ of 50.0 and $62.5 \mathrm{U} / \mathrm{ml}$, respectively for the two tested fungi. The anti-cancer activity was determined against cell lines of human colon carcinoma, liver carcinoma and breast carcinoma. About $70-80 \%$ cell death of carcinoma cell lines was obtained by using the crude L-asparaginase of either A. sydowii or F. oxysporum.
\end{abstract}

Keywords: Taguchi design, L-asparaginase, Filamentous fungi, Optimization, Anti-leukemic and anti-cancer cytotoxicity.

\section{Introduction}

L-asparaginase (L-asparagine amidohydrolase; E.C. 3.5.1.1) is a tetrameric protein, belongs to an amide group which catalyzes the hydrolysis of L-asparagine into L-aspartate and ammonia. The hydrolysis proceeds in two steps via a beta-acyl-enzyme intermediate in a mechanism described by Hill (1967). The catalytic reaction is essentially irreversible under physiological conditions (Nakahama et al., 1973 and Lubkowski et al., 1996).

The enzyme is considered to participate a major role in the asparagine metabolism of the cell (Imada et al., 1973 and Zuo et al., 2014). L-Asparaginase constitutes the largest group of therapeutic enzymes as they account for about $40 \%$ of the total worldwide sale of anti-leukemic and anti-lymphoma agents (Clavell et al., 1986 and Shrivastava et al., 2016).

L-asparagine is an amino acid required both by normal cells as well as cancer cells for the production of protein. Normal cells synthesize this amino acid by the catalytic activity of asparagine synthetase from aspartic acid and glutamine. However, neoplastic cells can not produce L-asparagine due to the low levels of L-asparagine synthetase and they depend on cellular pools of L-asparagine for their growth (Keating et al., 1993 and Shrivastava et al., 2016). For this reason, L-asparaginase is an anti-neoplastic agent, used in the lymphoblastic leukemia chemotherapy and the commonest therapeutic practice is to inject intravenously free enzyme in order to decrease the blood concentration of L-asparagine affecting selectively the neoplastic cells (Hosamani

\#Corresponding author email: dinamoniem@gmail.com 
\& Kaliwal, 2011; Dange \& Peshwe, 2015; Cachumba et al., 2016; Sanjotha \& Manawadi, 2017 and Vidya et al., 2017).

L-asparaginase can be obtained from animals, plants and microorganisms. Microbial L-asparaginase was isolated from Escherichia coli or Erwinia carotovora with anti-leukemic activity. L-asparaginase hydrolyzes L-asparagine into L-aspartic acid and ammonia in leukemic cells, resulting in the depletion of asparagine, inhibition of protein synthesis, cell cycle arrest in the "G1" phase, and apoptosis in susceptible leukemic cell population (Krasotkina et al., 2004; Narta et al., 2007 and El-Naggar et al., 2016).Verma et al. (2007) classified bacterialtype L-asparaginase into subtypes I and II, which are defined by their intra-or extracellular localization. Type-I (cytosolic) has a lower affinity for L-asparagine, whereas type-II (periplasmic) has a high substrate affinity. However, L-asparaginase from bacterial origin can cause hypersensitivity in the longterm use, leading to allergic reactions and anaphylaxis. The search for other asparaginase sources, like eukaryotic microorganisms, may lead to an enzyme with less adverse effects. It has been observed that eukaryotic microorganisms like yeast, and filamentous fungi have a potential asparaginase production (Dhale \& MohanKuman, 2014; Indira et al., 2015; ELshafei \& El-Ghonemy, 2015; Isaac \& Abu-Tahon, 2016 and Bedaiwy et al., 2016). Therefore, there is a continuing need to screen new microorganisms in order to obtain strains capable of producing new and high yield of L-asparaginase.

The objective of the present work was to search for L-asparaginase from eukaryotic fungal sources for production of enzyme with less immunogenic and non-toxic properties.

\section{Materials and Methods}

\section{Isolation and identification of fungi}

Fungi were isolated from soil samples collected from garden and from air of the medical chambers of Tumor Institute, Kasr El Ainy, Cairo Governorate, Egypt. Dilution plate method (Johnson et al., 1959) was employed for isolation. The growing fungi were counted and maintained on potato dextrose agar (PDA) slants for further studies.

The developed fungal colonies were identified up to species level by macro-and microscopic examination through the help of the following references: Raper \& Fennell (1965) for the genus Aspergillus, Booth (1971, 1977) for the genus Fusarium and Moubasher (1993) for soil fungi in Qatar and other Arab countries. The identification of fungi was confirmed by Assuit University Mycological Centre (AUMC), Egypt.

\section{Molecular identification}

The two most active fungi producing L-asparagenase were identified on the basis of $18 \mathrm{~S} \mathrm{r}$ DNA amplification and sequencing as described by White et al. (1990). Sequencing was carried out and the results were compared to sequences held in GenBank databases using the BLAST program (Altschul et al., 1997). Closely related or phylogentically relevant sequences were obtained from the GenBank databases and sequencing were aligned using ClustalW programs (Tamura et al., 2011). The evolutionary tree was inferred by using Neighbor Joining method using MEGA 5.05 software. The 18S rDNA gene sequence of strain (975 nucleotides) has been deposited in GenBank with nucleotide sequence (Wilson \& Walker, 1995; Oliver \& Schweizer, 1999 and Edward, 2001).

Qualitative and quantitative screening of L-asparaginase

All isolated fungi were assayed qualitatively for their L-asparaginase activity. A $2.5 \%$ stock of phenol red indicator was prepared in ethanol $(96 \%)$ and the $\mathrm{pH}$ was adjusted to 7.0 using 1.0 $\mathrm{N} \mathrm{NaOH}$. Different volumes of the stock solution of the phenol red dye, ranging from 0.05 to $0.2 \%$, were added to $100 \mathrm{ml}$ of modified Czapek's Dox Agar medium (i) without dye and (ii) without L-asparagine (instead of $\mathrm{NaNO}_{3}$ ) as nitrogen source according to the method described by Gulati et al. (1997). The modified Czapek's Dox Agar medium (g/L) consisting of glucose, 2.0; L-asparagine, $10.0 ; \mathrm{KH}_{2} \mathrm{PO}_{4}, 1.52 ; \mathrm{KCl}, 0.52$; $\mathrm{MgSO}_{4} .7 \mathrm{H}_{2} \mathrm{O}, 0.52$ and Agar, 20. The medium was sterilized by autoclaving, then the desired phenol red concentrations containing sterilized medium was poured in each plate and left to solidify. The plates were then inoculated with a mycelium disc, cut from the margin of actively growing colonies of 96 hours old culture of the test fungi by a sterile cork borer and incubated at $28 \pm 1^{\circ} \mathrm{C}$ for $48 \mathrm{~h}$. The L-asparaginase activity was measured by the diameter of pink zone resulted from ammonia liberation which turns the phenol red to pink color.

Quantitative assay of L-asparaginase 
activity in submerged cultures was carried out using modified Czapek's Dox liquid medium. Erlenmeyer conical flasks $250 \mathrm{ml}$ containing 50 $\mathrm{ml}$ of the appropriate medium were inoculated with each of the test organisms. Cultures were incubated under shaking at $100 \mathrm{rpm}$ at $28 \pm 1^{\circ} \mathrm{C}$ for $48 \mathrm{~h}$ in a sterile controlled environment shaking incubator (Model G25R; New Brunswick Scientific Co. Inc., Edison, NJ). Noninoculated media served as control. The fungal cultures were harvested by filtration through Whatman No. 1 filter paper in Büchner funnels. The resulting mycelial mat of each fungal culture was rinsed with hot water, oven dried to constant weight at $80^{\circ} \mathrm{C}$, to determine dry mass values. The culture filtrates were clarified through four layers of cheesecloth and centrifuged at 15000 $\mathrm{xg}$ for 20 min at $-5^{\circ} \mathrm{C}$ using a Beckman J-21 $\mathrm{B}$ cooling centrifuge. The supernatant (crude enzyme source) was used immediately in the assay. L-asparaginase activities were estimated in culture filtrates by Nesselerization (Imada et al., 1973). A reaction mixture containing $0.9 \mathrm{ml}$ of Tris- $\mathrm{HCl}$ buffer $(0.05 \mathrm{M}$ and $\mathrm{pH} 8.6), 0.1 \mathrm{ml}$ of crude enzyme source of fungal species and $0.5 \mathrm{ml}$ of $0.01 \mathrm{M} \mathrm{L-asparagine} \mathrm{as} \mathrm{substrate} \mathrm{(Sigma,} \mathrm{St.}$ Lowis, MO., USA) were added and the volume was completed to $2.0 \mathrm{ml}$ with distilled water. The reaction was incubated at $30^{\circ} \mathrm{C}$ for $30 \mathrm{~min}$. After the incubation period, the reaction mixture was stopped by adding $0.5 \mathrm{ml}$ of $1.5 \mathrm{M}$ trichloroacetic acid (TCA). From the reaction mixture aliquots of $0.2 \mathrm{ml}$ were added to distilled water $(3.4 \mathrm{ml})$ and to that Neesler's reagent $(0.4 \mathrm{ml})$ and incubated for $20 \mathrm{~min}$ at room temperature $\left(28 \pm 1^{\circ} \mathrm{C}\right)$. The absorbance was recorded at a wavelength of 450 $\mathrm{nm}$ with a UV-spectrophotometer. Blank tubes were prepared by adding the enzyme source after the addition of TCA. One international unit of L-asparaginase (IU) is the amount of enzyme required to release $1 \mu \mathrm{mol}$ of ammonia per min per $\mathrm{ml}$ under the assay conditions, calculated by the following equation:

Units $/$ ml enzyme $=\frac{\left(\boldsymbol{\mu M} \text { of } \mathbf{~ N H}_{3} \text { Liberated }\right)(2.5)}{(\mathbf{0 . 1})(30)(\mathbf{1})}$

where: $2.5=$ Initial volume of reaction mixture $(\mathrm{ml}) ; 0.1=$ Volume of reaction mixture in final reaction $(\mathrm{ml}) ; 30=$ Incubation time $(\mathrm{min}) ; 1=$ Volume of enzyme used (ml).
Optimization of culture conditions for L-asparaginase production by two selected fungal species

Based on their high ability to produce L-asparaginase, A. sydowii and F. oxysporum were selected for further studies to optimize the cultural conditions for production and activity of L-asparaginase, according to Taguchi design (Prasad et al., 2005). The experimental design and methodology involve the establishment of large number of experimental situation described as orthogonal arrays to reduce experimental errors and to enhance the efficiency and reproducibility of the laboratory experiments. In the present investigation, the three levels of variation factors were considered and the size of experimentation was represented by symbolic arrays indicating 18 experimental trails. All the factors have been assigned with three levels except L-asparagine with two levels $\left(2^{1}\right)$ with a layout of L18 $\left(2^{1} \mathrm{x}\right.$ $3^{7}$ ). The total degree of freedom is equal to the number of trials minus one i.e., 17.

Submerged fermentation experiments were carried out in $250 \mathrm{ml}$ Erlenmeyer conical flasks, each, containing $100 \mathrm{ml}$ of production medium composed of different levels of the following $(\mathrm{g} / \mathrm{L}) \mathrm{L}$-asparagine $(5.0,10)$, glucose $(1.0,2.0,3.0), \mathrm{KH}_{2} \mathrm{PO}_{4}(1.0,1.52,2.0), \mathrm{KCl}$ $(0.25,0.52,0.75), \mathrm{MgSO}_{4} .7 \mathrm{H}_{2} \mathrm{O}(0.25,0.52$, 0.75 ). Temperature was adjusted at 20,30 and $40^{\circ} \mathrm{C}$, agitation speed was adjusted at 50,100 and $200 \mathrm{rpm}$ and $\mathrm{pH}$ was adjusted at 5.0,7.0 and 9.0. Erlenmeyer conical flasks containing different media were sterilized as a previously described. Fungal disc $(5 \mathrm{~mm})$, cut from the growing margin of 96 hours-old culture, was inoculated for each flask. The inoculated flasks were incubated at 20,30 and $40^{\circ} \mathrm{C}$ for 5 days in orbital shaking incubator. Mycelial mats were collected by filtration and the filtrate was used for L-asparaginase assay (Prasad et al., 2005).

Eighteen media used in this experimentation were prepared according to Taguchi method of orthogonal array experimental design, where 18 probabilities were resulted from the interaction of eight factors (L-asparagine, glucose, $\mathrm{KH}_{2} \mathrm{PO}_{4}$, $\mathrm{KCl}, \mathrm{MgSO}_{4} \cdot 7 \mathrm{H}_{2} \mathrm{O}$, temperature, agitation speed and $\mathrm{pH}$ ) in addition to the best medium no."19" as shown in Table 1. 
TABLE 1. Optimization factorial design of modified Czapek's Dox media for maximization of L-asparaginase production by Aspergillus sydowii and Fusarium oxysporum

\begin{tabular}{|c|c|c|c|c|c|c|c|c|}
\hline \multirow{2}{*}{$\begin{array}{l}\text { Modified } \\
\text { Czapek's } \\
\text { Dox media } \\
\text { number }\end{array}$} & \multicolumn{5}{|c|}{ Components $(\mathrm{g} / \mathrm{L})$} & \multirow{2}{*}{$\begin{array}{c}\text { Temp. } \\
\left({ }^{\circ} \mathrm{C}\right)\end{array}$} & \multirow{2}{*}{$\begin{array}{c}\text { Agitation } \\
\text { speed (rpm) }\end{array}$} & \multirow{2}{*}{ pH } \\
\hline & L-asparagine & Glucose & $\mathrm{KH}_{2} \mathrm{PO}_{4}$ & KCI & $\mathrm{MgSO}_{4} \cdot 7 \mathrm{H}_{2} \mathrm{O}$ & & & \\
\hline 1 & 5.0 & 1.0 & 1.0 & 0.25 & 0.25 & 20 & 50 & 5.0 \\
\hline 2 & 5.0 & 1.0 & 1.52 & 0.52 & 0.52 & 30 & 100 & 7.0 \\
\hline 3 & 5.0 & 1.0 & 2.0 & 0.75 & 0.75 & 40 & 200 & 9.0 \\
\hline 4 & 5.0 & 2.0 & 1.52 & 0.25 & 0.25 & 40 & 200 & 7.0 \\
\hline 5 & 5.0 & 2.0 & 2.0 & 0.52 & 0.52 & 20 & 50 & 9.0 \\
\hline 6 & 5.0 & 2.0 & 1.0 & 0.75 & 0.75 & 30 & 100 & 5.0 \\
\hline 7 & 5.0 & 3.0 & 1.0 & 0.25 & 0.52 & 30 & 200 & 9.0 \\
\hline 8 & 5.0 & 3.0 & 1.52 & 0.52 & 0.75 & 40 & 50 & 5.0 \\
\hline 9 & 5.0 & 3.0 & 2.0 & 0.75 & 0.25 & 20 & 100 & 7.0 \\
\hline 10 & 10.0 & 1.0 & 2.0 & 0.75 & 0.75 & 30 & 50 & 7.0 \\
\hline 11 & 10.0 & 1.0 & 1.0 & 0.25 & 0.25 & 40 & 100 & 9.0 \\
\hline 12 & 10.0 & 1.0 & 1.52 & 0.52 & 0.52 & 20 & 200 & 5.0 \\
\hline 13 & 10.0 & 2.0 & 2.0 & 0.25 & 0.52 & 40 & 100 & 5.0 \\
\hline 14 & 10.0 & 2.0 & 1.0 & 0.52 & 0.75 & 20 & 200 & 7.0 \\
\hline 15 & 10.0 & 2.0 & 1.52 & 0.75 & 0.25 & 30 & 50 & 9.0 \\
\hline 16 & 10.0 & 3.0 & 1.52 & 0.25 & 0.75 & 20 & 100 & 9.0 \\
\hline 17 & 10.0 & 3.0 & 2.0 & 0.52 & 0.25 & 30 & 200 & 5.0 \\
\hline 18 & 10.0 & 3.0 & 1.0 & 0.75 & 0.52 & 40 & 50 & 7.0 \\
\hline 19 & 10.0 & 2.0 & 1.0 & 0.25 & 0.52 & 40 & 100 & 5.0 \\
\hline
\end{tabular}

Dry mass yields $(\mathrm{g} / 100 \mathrm{ml})$ and L-asparaginase activities $(\mathrm{U} / \mathrm{ml})$ of $A$. sydowii and $F$. oxysporum were determined as previously described.

In vitro assay of the anti-leukemic activity of the crude L-asparaginase

Cell culture

Raw murine macrophage (RAW 264.7) was purchased from the American Type Culture Collections. Cells were routinely cultured in RPMI-1640 medium supplemented with 10\% fetal bovine serum (FBS), $2.0 \mathrm{mM}$ L-glutamine, containing $100 \mathrm{U} / \mathrm{ml}$ penicillin $\mathrm{G}$ sodium, 100 $\mu \mathrm{g} / \mathrm{ml}$ streptomycin sulphate, and $250 \mu \mathrm{g} /$ $\mathrm{ml}$ amphotericin B. Cells were maintained in humidified air containing $5.0 \% \quad \mathrm{CO}_{2}$ at $37^{\circ} \mathrm{C}$. RAW 264.7 cells were collected by scraping. All experiments were repeated four times and the data was represented as mean \pm S.D. All cell culture materials were obtained from Cambrex, Bioscience (Copenhagen, Denmark).

Cell viability and cytotoxicity assay

The effect of tested samples on the viability of RAW 264.7 Leukemia cells was measured according to the method described by Hansen et al. (1989) using the MTT cells assay (3-4,5-dimethylthiazole2-yl- [2,5-diphenyltetrazolium bromide]). MTT assay is based on the ability of active mitochondrial dehydrogenase enzyme of living cells to cleave the tetrazolium rings of the yellow MTT and form a dark blue insoluble formazan crystals which can not penetrate through cell membranes, resulting in their accumulation within healthy cells. Lysis of the cells results in the liberation of crystals, which are then solubilized. The number of viable cells is directly proportional to the level of soluble formazan dark blue color. The extent of the reduction of MTT was quantified by measuring the absorbance at $570 \mathrm{~nm}$. MTT solution was prepared as follows: $5.0 \mathrm{mg} /$ $\mathrm{ml}$ of MTT in $0.9 \% \mathrm{NaCl}$; acidified isopropanol: $0.04 \mathrm{~N} \mathrm{HCl}$ in absolute isopropanol.

Cytotoxicity assay was studied as follows: cells $0.5 \mu \mathrm{L}$ of $10^{5}$ cells/well in serum-free media were plated in a flat bottom 96- well microplate, and treated with $20 \mu \mathrm{L}$ of different concentrations of each tested crude L-asparaginase produced by $A$. sydowii or $F$. oxysporum for $24 \mathrm{~h}$ at $37^{\circ} \mathrm{C}$, in humidified air containing $5.0 \% \mathrm{CO}_{2}$. After incubation, media were removed and $40 \mu \mathrm{L}$ MTT solution/well were added and incubated for an additional $4 \mathrm{~h}$. MTT crystals were solubilized by adding $180 \mu \mathrm{L}$ of acidified isopropanol/well and plate was shaken at room temperature, followed by photometric determination at the absorbance of $570 \mathrm{~nm}$ using 96 wells microplate ELISA reader. Triplicates were performed for each crude enzyme concentration and the average was calculated. Data were expressed as the percentage of relative 
viability compared with the untreated control cells, as relative fold of increase in the cell viability (Hansen et al., 1989).

The fold increase in the relative viability (R.V.) was calculated using the following equation: Relative Viability $=\frac{\text { R.V. }- \text { Absorbance of treated cells }}{\text { Absorbance of control untrated cells }} \times 100$

Cytotoxicity assay against tumor cell lines

The cellular toxicity of the crude L-asparaginase produced by either $A$. sydowii or $F$. oxysporum were assessed in vitro by Skehan et al. (1990). The assay was done on cell monolayers of human colon carcinoma cell line (HCT116), liver carcinoma cell line (HEPG2), and breast carcinoma cell line (MCF-7) in the tissue culture plates. The cells were plated in 96-multiwell plate $\left(10^{5}\right.$ cells/well) for 24 $\mathrm{h}$ before treatment with the crude L-asparaginase. The crude enzyme of each tested fungus was added to the cell monolayers triplicate to reach a final concentration of $50 \mu \mathrm{g} / \mathrm{ml}$. The monolayer cells were incubated with the fractions for $48 \mathrm{~h}$ at $37^{\circ} \mathrm{C}$ and in humidified atmosphere of $5.0 \% \mathrm{CO}_{2}$. After $48 \mathrm{~h}$, cells were fixed by adding trichloroacetic acid (TCA) in each well for $1 \mathrm{~h}$ and washed five times with tap water to remove TCA. Thereafter, the cells were stained for $30 \mathrm{~min}$ with $0.4 \%$ (w/v), SulfoRhodamine-B (SRB) stain dissolved in 1.0\% acetic acid. Unbounded dye was removed by four washes with $1.0 \%$ acetic acid, and protein- bound dye was extracted with $10 \mathrm{mM}$ buffered Trisbase [tris-(hydroxymethyl)aminomethane] for determination of optical density in a computerinterfaced. The color intensity was measured in ELISA reader at $564 \mathrm{~nm}$. Cells free blank was used for background correction of the absorbance. The viability was calculated as percentage relative to the solvent control absorbance value after subtracting the contribution from cell-free blank.

The results are represented as viability $\%$ or cytotoxicity $\%$ (obtained by subtraction of the $\%$ viability value from 100 ).

\section{$\underline{\text { Results }}$}

Air and soil- borne mycobiota isolated in the present study

The data in Table 2 revealed that a total of 16 fungal species belonging to 8 genera were isolated from the two studied localities with total count of 143 isolates. Sixty seven isolates were recovered from the air constituting related to 14 species while seventy six isolates were recovered from the soil related to 16 species.Aspergillus sydowii was the most dominant species in air and soil with $26.87 \%$ and $21.06 \%$ relative density, respectively. $A$. terreus shared $A$. sydowii with 16 isolates from air and soil with relative density of $11.19 \%$. A. ochraceus was represented by 15 isolates constituting $10.49 \%$ of which nine isolates were recorded from air and six from soil. According to the relative density, $F$. poae, F. incarnatum, F. oxysporum and A. flavus ranked fourth constituting 7.69, 6.99, 6.99 and $6.29 \%$, respectively, with the major count isolated from the soil. Each of the remaining fungal species constituted less than $5.0 \%$ relative density including A. japonicus, A. parasiticus, A. ustus, Epicoccum nigrum, Paecilomyces variotii, Saccharomycopsis fibuligera and Ulocladium consortiale. It is noticed that Curvularia lunata and Trichoderma longibrqachiatum were recovered from soil locality but were completely missed from air environment.

\section{L-asparaginase assay}

All isolated fungal species were tested for their ability to produce extracellular L-asparaginase using diffusion plate method.

Results in Table 3 indicated that $F$. oxysporum, $F$. incarnatum, A. terreus and A. sydowii were strong asparaginase producers. However, Epicoccum nigrum, F. poae, A. ustus, A. japonicus and $A$. ochraceus were of moderate asparaginolytic activities. Weak L-asparaginase production was observed in the case of Saccharomycopsis fibuligera and Ulocladium consortiale. L-asparaginase induction and activity were significantly affected by phenol red concentration. Regardless of Paecilomyces variotii, Saccharomycopsis fibuligera and Ulocladium consortiale which showed their maximum activity of L-asparaginase at $0.05 \%$ phenol red, all tested fungi exhibited better L-asparaginase production at $0.07 \%$. The maximum production of L-asparaginase was achieved by $F$. oxysporum, $A$. sydowii and $F$. incarnatum at $0.07 \%$ measuring $4.9,4.6$ and 4.5 $\mathrm{cm}$, respectively. At higher levels of phenol red concentrations (0.09 and $0.2 \%$ ) L-asparaginase production was markedly retarded. Considering linear growth, it was observed that addition of phenol red was inhibitory for all fungal species, regardless of all concentrations used, as compared to control which lack the phenol red. Appearing of pink zone around the colonies indicates an increase in $\mathrm{pH}$, which originate from ammonia accumulation in the medium. 
TABLE 2. Fungi recovered from air and soil of tumor institute, KasrEl Ainy, Egypt .

\begin{tabular}{|c|c|c|c|c|c|c|}
\hline \multirow[b]{2}{*}{ Fungal species } & \multicolumn{2}{|c|}{ Air fungi } & \multicolumn{2}{|c|}{ Soil fungi } & \multicolumn{2}{|c|}{ Total } \\
\hline & $\begin{array}{l}\text { Total } \\
\text { count }\end{array}$ & $\begin{array}{c}\text { Relative } \\
\text { density } \\
(\%)\end{array}$ & $\begin{array}{l}\text { Total } \\
\text { count }\end{array}$ & $\begin{array}{c}\text { Relative } \\
\text { density } \\
(\%)\end{array}$ & $\begin{array}{l}\text { Total } \\
\text { count }\end{array}$ & $\begin{array}{c}\text { Relative } \\
\text { density } \\
(\%)\end{array}$ \\
\hline Aspergillus flavus var. columnaris Link & 3 & 4.48 & 6 & 7.89 & 9 & 6.29 \\
\hline Aspergillus japonicus Link & 2 & 2.99 & 4 & 5.26 & 6 & 4.20 \\
\hline Aspergillus ochraceus Wilhelm & 9 & 13.43 & 6 & 7.89 & 15 & 10.49 \\
\hline Aspergillus parasiticus link & 1 & 1.49 & 3 & 3.95 & 4 & 2.80 \\
\hline $\begin{array}{l}\text { Aspergillus sydowii (Bainier\&Sartory) } \\
\text { Thom \& Church }\end{array}$ & 18 & 26.87 & 16 & 21.06 & 34 & 23.78 \\
\hline Aspergillus terreus Thom & 13 & 19.40 & 3 & 3.95 & 16 & 11.19 \\
\hline $\begin{array}{l}\text { Aspergillus ustus (Bainier) Thom \& } \\
\text { Church }\end{array}$ & 3 & 4.48 & 2 & 2.63 & 5 & 3.49 \\
\hline Curvularia lunata (Walker) Boedijn & 0 & 0.0 & 4 & 5.26 & 4 & 2.80 \\
\hline Epicoccum nigrum Link & 3 & 4.48 & 1 & 1.32 & 4 & 2.80 \\
\hline Fusarium incarnatum (Rob.) Sacc. & 3 & 4.48 & 7 & 9.21 & 10 & 6.99 \\
\hline Fusarium oxysporum Schl. F. 1. Wollenw. & 4 & 5.97 & 6 & 7.89 & 10 & 6.99 \\
\hline $\begin{array}{l}\text { Fusarium poae (Peck) } \\
\text { Wollenw.f. pallens Wollenw. }\end{array}$ & 3 & 4.48 & 8 & 10.53 & 11 & 7.69 \\
\hline Paecilomyces variotii (Bainier) & 2 & 2.99 & 1 & 1.32 & 3 & 2.10 \\
\hline $\begin{array}{l}\text { Saccharomycopsis fibuligera (Lindner) } \\
\text { Klocker }\end{array}$ & 1 & 1.49 & 1 & 1.32 & 2 & 1.39 \\
\hline Trichoderma longibrachiatum Pers & 0 & 0.0 & 5 & 6.58 & 5 & 3.50 \\
\hline $\begin{array}{l}\text { Ulocladium consortiale } \\
\text { (Thumen) Simmons }\end{array}$ & 2 & 2.99 & 3 & 3.95 & 5 & 3.50 \\
\hline Total isolates & 67 & 100 & 76 & 100 & 143 & 100 \\
\hline Total number of species & 14 & - & 16 & - & 16 & - \\
\hline
\end{tabular}

The fungal species under test were quantitatively assayed for L-asparaginase activity in the culture filtrate (Table 4). A. sydowii and $F$. oxysporum were the most potent species in L-asparaginase production where the enzyme activity reached 3.98 and $3.91 \mathrm{U} / \mathrm{ml}$, respectively. $A$. terreus, $F$. incarnatum and $F$. poe showed considerable activity recording $2.91,2.41$ and $2.21 \mathrm{U} / \mathrm{ml}$, respectively. Saccharomycopsis fibuligera, Ulocladium consortiale and Trichodrema longibrachiatum recorded the least enzyme activity (less than $1.0 \mathrm{U} / \mathrm{mL}$ for each).

\section{Molecular identification of the most potent fungal isolates}

The identification of the most potent fungal isolates producing L-asparaginase (Aspergillus sydowii and Fusarium oxysporum) was further confirmed by performing $18 \mathrm{~S}$ rDNA sequencing. The obtained sequences of both fungal strains were deposited in the GenBank given accession Numbers of MG846707 for Aspergillus sydowii strain D11 and MG846495 for Fusarium oxysporum strain D3.

The phylogenetic tree (Fig. 1) showed high similarities of these fungi with closely related strains accessed from the GenBank.

\section{Optimization of L-asparaginase production}

High L-asparagenolytic activity was achieved in modified medium "19" composed of: (g/L) L-asparagine, 10; glucose, 2.0; $\mathrm{KH}_{2} \mathrm{PO}_{4}, 1.0 ; \mathrm{KCl}$, $0.25 ; \mathrm{MgSO}_{4} .7 \mathrm{H}_{2} \mathrm{O}, 0.52$; after 5 day-incubation at $40^{\circ} \mathrm{C}$ and agitation speed of $100 \mathrm{rpm}$ with the adjustment of $\mathrm{pH}$ at 5.0 as shown in Table 5. In this medium, enzyme activity of 146 and $143 \mathrm{U} /$ $\mathrm{ml}$ was detected in the assay mixture, and the dry mass yield measured 1.26 and $1.19 \mathrm{~g} / 100 \mathrm{ml}$ for A. sydowii and $F$. oxysporum, respectively. 


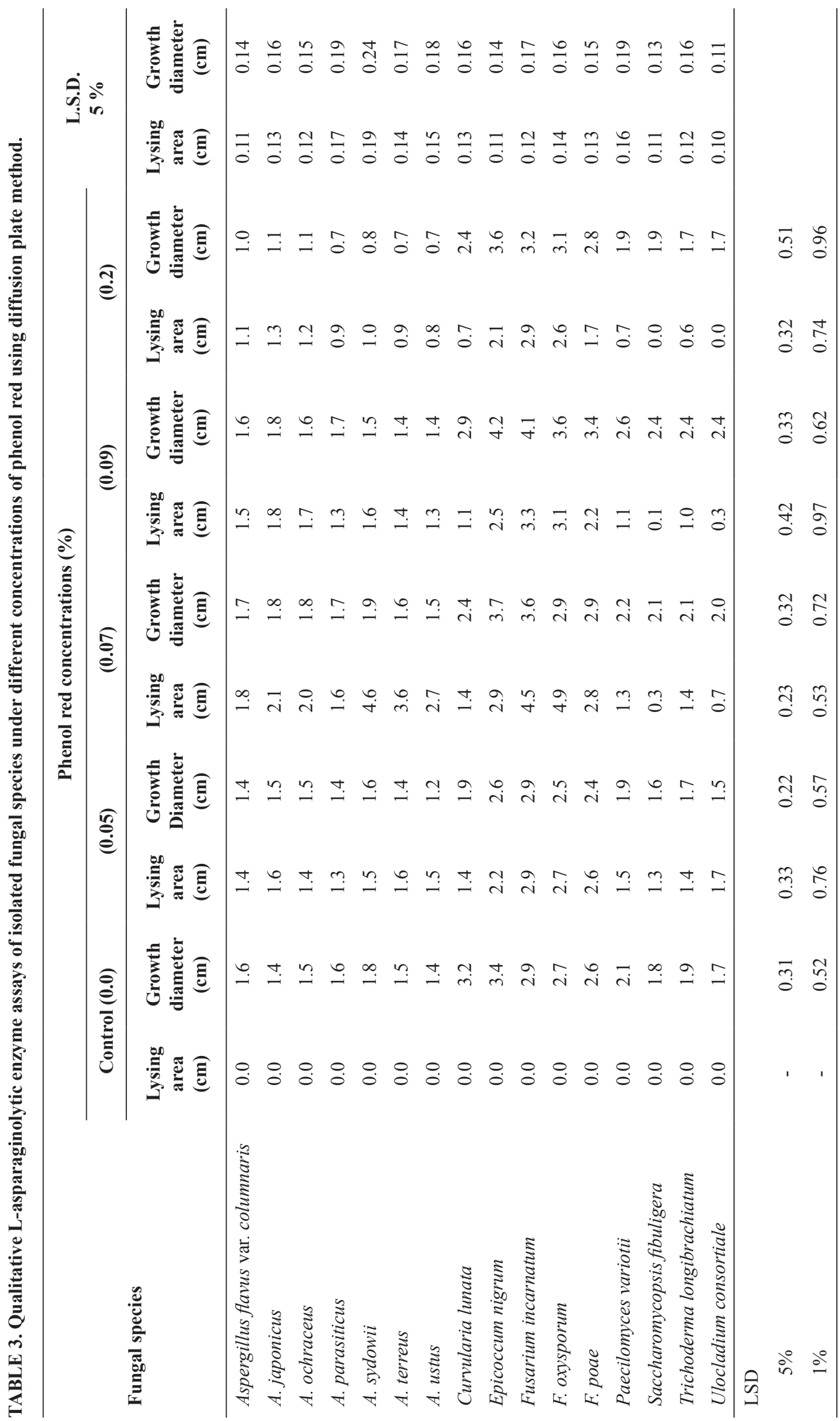


TABLE 4. Quantitative $L$-asparaginolytic enzyme assay of the investigated isolated fungal species in culture liquid media after $48 \mathrm{~h}$ incubation period.

\begin{tabular}{lcc}
\hline Fungal species & $\begin{array}{c}\text { L-asparaginase activity } \\
(\mathbf{U} / \mathbf{m l})\end{array}$ & $\begin{array}{c}\text { Dry mass yield } \\
\text { (g/100 } \mathbf{~ m})\end{array}$ \\
\hline Aspergillus flavusvar. & 1.69 & 0.631 \\
columnaris & 1.71 & 0.592 \\
A. japonicus & 1.92 & 0.693 \\
A. ochraceus & 1.42 & 0.614 \\
A. parasiticus & 3.98 & 0.966 \\
A. sydowii & 2.91 & 0.914 \\
A. terreus & 1.40 & 0.841 \\
A. ustus & 1.31 & 0.632 \\
Curvularia lunata & 1.72 & 0.924 \\
Epicoccum nigrum & 2.41 & 0.822 \\
Fusariumi ncarnatum & 3.91 & 0.941 \\
F. xysporum & 2.21 & 0.871 \\
F. poae & 0.82 & 0.552 \\
Paecilomyces variotii & 0.51 & 0.286 \\
Saccharomycopsisfibuligera & 0.68 & 0.456 \\
Trichoderma longibrachiatum & 0.62 & 0.393 \\
Ulocladium consortiale & & \\
\hline LSD 5\% & 0.72 & 0.31 \\
\multicolumn{1}{c}{ 1\% } & 1.21 & 0.52 \\
\hline
\end{tabular}

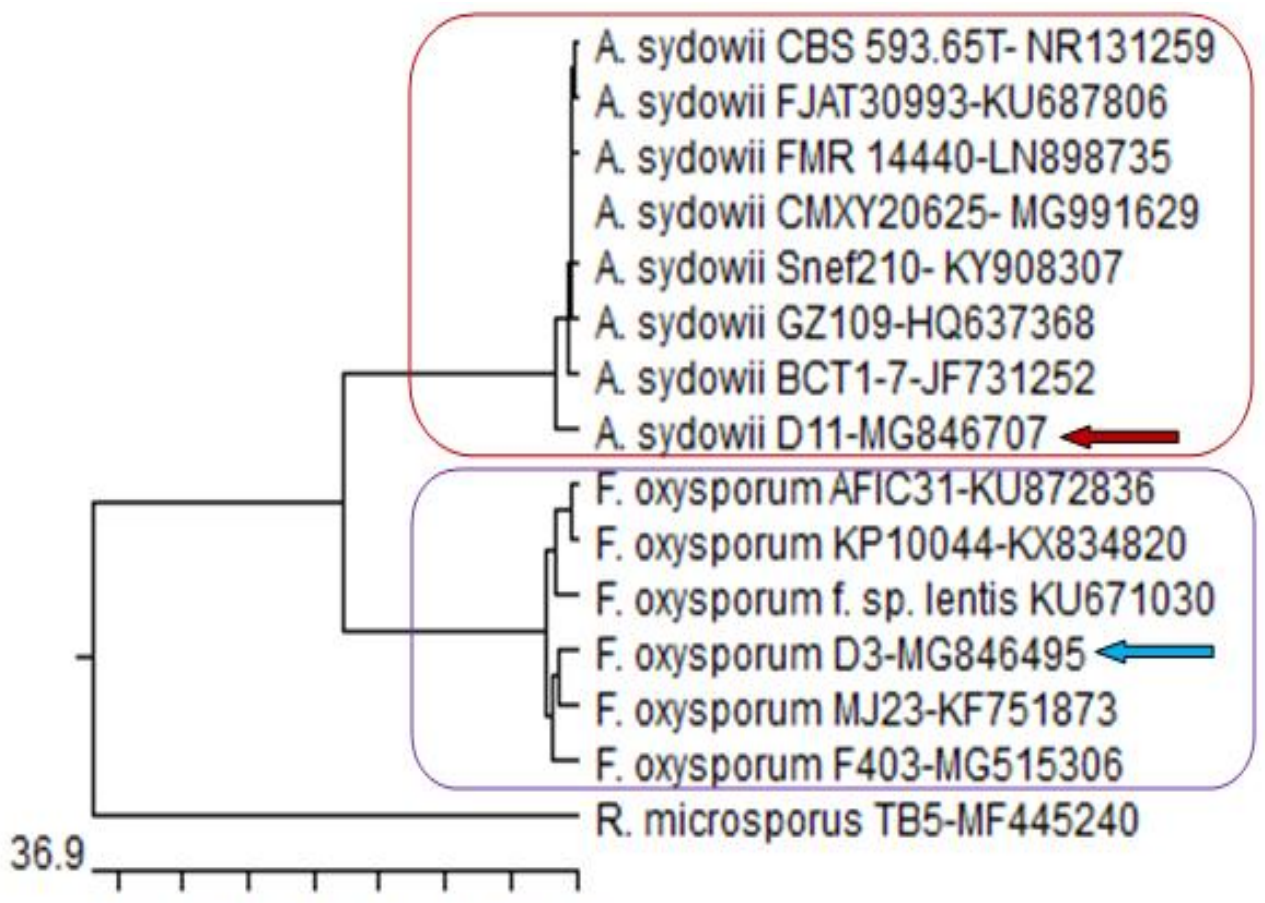

$353025201510 \quad 5 \quad 0$ Nucleotide Substitutions $(x 100)$

Fig.1. Phylogenetic tree showing genetic realationship between Aspergillus sydowii (MG 846707) and Fusarium oxysporum (MG846495) isolated in the present study (see arrows) and other closely related strains accessed from the GenBank. $R$. microsporus is included in the tree as an outgroup strain. $(\mathrm{A}=$ Aspergillus, $\mathrm{F}=$ Fusarium, R=Rhizopus). 
TABLE 5. Optimization factorial design for maximization of production and activity of $L$-asparaginase $(\mathrm{U} / \mathrm{ml})$ in culture filtrate of Aspergillus sydowiin and Fusarium oxysporum after 5 days incubation period.

\begin{tabular}{lcccc}
\hline & \multicolumn{2}{c}{ A. sydowii } & \multicolumn{2}{c}{ F. oxysporum } \\
\cline { 2 - 5 } No of experiments & $\begin{array}{c}\text { L-asparaginase } \\
\text { activity }\end{array}$ & $\begin{array}{c}\text { Dry mass yield } \\
\text { (g/100 } \mathbf{~ m l ) ~}\end{array}$ & $\begin{array}{c}\text { L-asparaginase } \\
\text { activity }\end{array}$ & $\begin{array}{c}\text { Dry mass yield } \\
\text { (g/100 ml) }\end{array}$ \\
\hline 1 & 69 & 0.861 & 67 & 0.840 \\
2 & 46 & 0.820 & 44 & 0.801 \\
3 & 37 & 0.621 & 33 & 0.603 \\
4 & 76 & 0.892 & 73 & 0.874 \\
5 & 83 & 0.961 & 80 & 0.947 \\
6 & 123 & 1.07 & 121 & 1.03 \\
7 & 48 & 0.811 & 46 & 0.800 \\
8 & 45 & 0.807 & 43 & 0.796 \\
9 & 39 & 0.632 & 36 & 0.620 \\
10 & 46 & 0.826 & 43 & 0.802 \\
11 & 88 & 0.973 & 85 & 0.952 \\
12 & 47 & 0.829 & 44 & 0.801 \\
13 & 127 & 1.12 & 124 & 1.02 \\
14 & 85 & 0.952 & 81 & 0.933 \\
15 & 53 & 0.831 & 50 & 0.811 \\
16 & 67 & 0.842 & 63 & 0.820 \\
17 & 63 & 0.836 & 60 & 0.817 \\
18 & 56 & 0.847 & 52 & 0.828 \\
\hline LSD 5\% & 146 & 1.26 & 143 & 1.19 \\
\hline & 0.9 & 0.12 & 0.8 & 0.31 \\
\hline
\end{tabular}

Among the 18 different types of media in the experimental factorial design, medium " 13 " composed of $(\mathrm{g} / \mathrm{L})$ L-asparagine, 10; glucose, $2.0 ; \mathrm{KH}_{2} \mathrm{PO}_{4}, 2.0 ; \mathrm{KCl}, 0.25 ; \mathrm{MgSO}_{4} .7 \mathrm{H}_{2} \mathrm{O}, 0.52$; in addition to medium " 6 " composed of $(\mathrm{g} / \mathrm{L})$ L-asparagine, 5.0; glucose, 2.0; $\mathrm{KH}_{2} \mathrm{PO}_{4}, 1.0 ; \mathrm{KCl}$, 0.75 ; $\mathrm{MgSO}_{4} .7 \mathrm{H}_{2} \mathrm{O}, 0.75$; temp., $30^{\circ} \mathrm{C}$; agitation speed, $100 \mathrm{rpm}$ and $\mathrm{pH} 5.0$ were also suitable for L-asparaginase production. The recorded results showed L-asparaginolytic activity of 127 and 123 for A. sydowii and 124 and $121 \mathrm{U} / \mathrm{ml}$ for F. oxysporum in case of media no " 6 and 13 ", respectively. Media " 4 , 5, 11 and 14" induced moderate L-asparaginolytic activity in the culture filtrates of the tested fungi. The remaining medium types resulted in weak activity of L-asparaginase with a minimum value recorded by at medium " 3 "with 37 and $33 \mathrm{U} / \mathrm{ml}$ enzyme activities for A. sydowii and F. oxysporum, respectively.

The dry mycelial mass of $A$. sydowii and $F$. oxysporum ranged from 0.621 to 1.26 and from 0.603 to $1.19 \mathrm{~g} / 100 \mathrm{ml}$ respectively with the highest amounts being observed in cultures grown in the modified medium No. 19 as shown in Table 5.

\section{Therapeutic efficacy}

From the previous data (Table 6), the optimum modified medium(19) was selected for anti-leukemic activity and anti-cancer assay of L-asparaginase produced by $A$. sydowii and $F$. oxysporum.

Anti-leukemic activity of the crude L-asparaginase was tested against murine RAW 264.7 leukemia cells line using MTT viability assay. The results in Fig. 2 indicated that both of the crude L-asparaginase from $A$. sydowii and $F$. oxysporum exhibited anti-leukemic activities depending on $\mathrm{IC}_{50}$ of 50.0 and $62.5 \mathrm{U} / \mathrm{ml}$, respectively. The lower dose of the crude enzyme $(12.5 \mathrm{U} / \mathrm{ml})$ reduced the cell viability by about $20 \%$ with relative viability of $80.0 \%$ of the control, while the high dose $(100 \mathrm{U} /$ $\mathrm{ml})$ reduced cell viability by $75-85 \%$ with relative viability about $15-25 \%$ of the control for both fungi. 
In vitro anti-cancer test for the crude L-asparaginase $(50 \mu \mathrm{g} / \mathrm{ml})$ produced by A.sydowii and $F$. oxysporum, of either crude L-asparaginase was carried out on human colon carcinoma cell line (HCT116), liver carcinoma cell line (HEPG2) and breast carcinoma cell line (MCF-7). The results revealed that the cell death of human colon carcinoma cell line reached 70 and $73 \%$ in case of crude enzyme from $A$. sydowii and $F$. oxysporum, respectively. Higher anti-cancer activity (up to $80 \%$ ) was observed in case of liver and breast carcinoma cell lines (Fig. 3).

TABLE 6. Comparison between media composition exerting high $\mathrm{L}$-asparaginase activity from $A$. sydowii and $F$. oxysporum after 5 days incubation.

\begin{tabular}{|c|c|c|c|c|c|c|c|c|c|c|}
\hline \multirow{2}{*}{$\begin{array}{l}\text { Modified } \\
\text { Czapek's } \\
\text { Dox } \\
\text { media } \\
\text { number }\end{array}$} & \multirow{2}{*}{$\begin{array}{c}\text { L-asparagine } \\
(\mathrm{g} / \mathrm{L})\end{array}$} & \multirow{2}{*}{$\begin{array}{c}\text { Glucose } \\
\text { (g/L) }\end{array}$} & \multirow{2}{*}{$\begin{array}{c}\mathrm{KH}_{2} \mathrm{PO}_{4} \\
(\mathrm{~g} / \mathrm{L})\end{array}$} & \multirow{2}{*}{$\begin{array}{r}\mathrm{KCl} \\
(\mathrm{g} / \mathrm{L})\end{array}$} & \multirow{2}{*}{$\underset{(\mathrm{g} / \mathrm{L})}{\mathrm{MgSO}_{4} \cdot 7 \mathrm{H}_{2} \mathrm{O}}$} & \multirow{2}{*}{$\begin{array}{c}\text { Temp. } \\
\left({ }^{\circ} \mathrm{C}\right)\end{array}$} & \multirow{2}{*}{$\begin{array}{c}\text { Agitation } \\
\text { speed } \\
(\mathrm{rpm})\end{array}$} & \multirow{2}{*}{ pH } & \multicolumn{2}{|c|}{$\begin{array}{l}\text { L-asparaginase } \\
\text { activity }(\mathrm{U} / \mathrm{ml})\end{array}$} \\
\hline & & & & & & & & & A. sydowii & $\begin{array}{c}F \\
\text { oxysporum }\end{array}$ \\
\hline 19 & 10 & 2.0 & 1.0 & 0.25 & 0.52 & 40 & 100 & 5 & 146 & 143 \\
\hline 6 & 5.0 & 2.0 & 1.0 & 0.75 & 0.75 & 30 & 100 & 5 & 123 & 121 \\
\hline 13 & 10 & 2.0 & 2.0 & 0.25 & 0.52 & 40 & 100 & 5 & 127 & 124 \\
\hline 3 & 5.0 & 1.0 & 2.0 & 0.75 & 0.75 & 40 & 200 & 9 & 37 & 33 \\
\hline
\end{tabular}

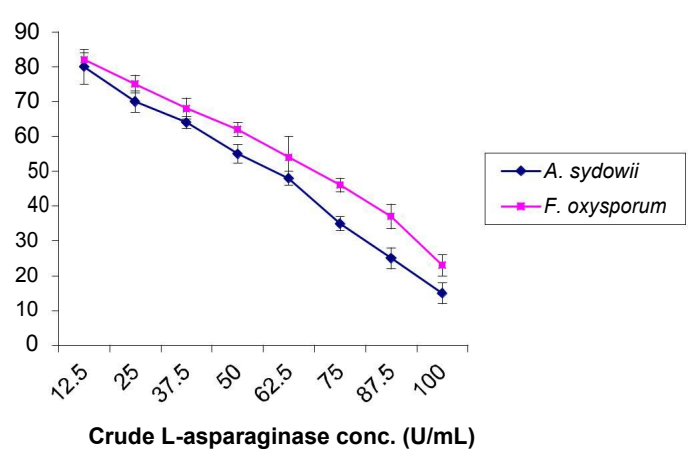

Fig. 2. Cell viability of RAW 246.7 Leukemia cells after the treatment with different concentrations of the crude L-asparaginase produced from $A$. sydowii and $F$. oxysporum for $48 \mathrm{~h}$ as measured by MTT assay.

\section{Discussion}

Recently a considerable attention has been paid to the isolation of bioactive compounds from eukaryotic microorganisms. Among the bioactive compounds produced by $A$. sydowii and $F$. oxysporum L-asparaginase were studied. Sixteen fungal species were isolated from air and soil environments of Tumor Institute, Kasr El Ainy, Cairo University, Egypt. Several of the isolated fungi were confirmed earlier by many investigators to be L-asparaginase producers. In the present study, $A$. sydowii and $F$. oxysporum were found to be the most efficient species in L- asparaginase production. In this respect, several species of Aspergillus including

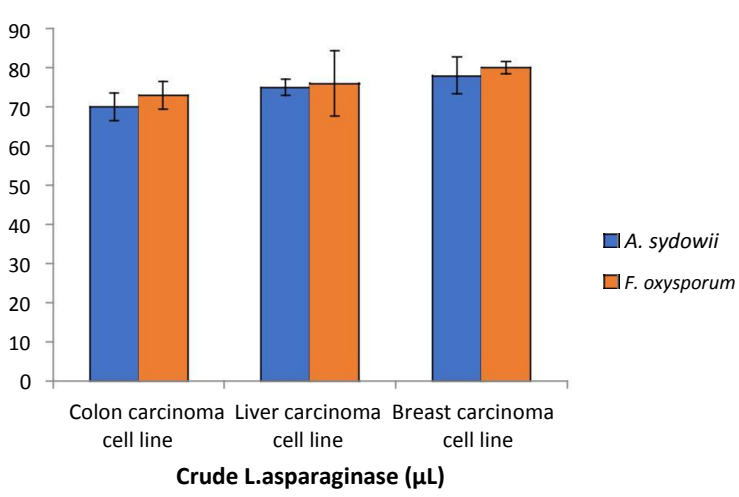

Fig. 3. Effect of the crude L-asparaginase produced by either $A$. sydowii or $F$. oxysporum on different carcinoma cell lines in vitro.

A. tamarii, A. niger, A. nidulans and $A$. terreus were recorded as L-asparaginase producers (Bedaiwy et al., 2016; Dange \& Peshwe, 2015; Archana \& Raja, 2014 and Farag et al., 2015). Similar investigations have been done with Fusarium spp. including $F$. anguioides, F. oxysporum, F. roseum, F. solani and F. equiseti (Nakahama et al., 1973; Niharika \& Supriya, 2014; Hosamani \& Kaliwal, 2011; Radhika \& Girisham, 2012 and Ruma et al., 2017).

The screening system was comparable with those previously reported for production of L-asparaginase by filamentous fungi (El-Sayed, 2008). Also, the differences in the production level 
of L-asparaginase by the different investigated species may be attributed to either the fermentation conditions or to the tested fungi strain (Bedaiwy et al., 2016). Several fungi isolated from different environments have efficiency and potentiality to produce L-asparaginase including Penicillium isolated from mangrove ecosystem of Bhitarkanika (Guptaet al.,2009),Penicillium citrinum, Aspergillus ochraceus, Fusarium oxysporum, Alternaria alternata, Rhizopus spp. and Trichoderma viride isolated from the soil (Niharika \& Supriya, 2014 and Lincoln et al., 2015), Aspergillus, Penicillium and Fusarium isolated from the marine environment of the Red Sea Coast of Egypt (Farag et al., 2015), Aspergillus terreus as endophytic fungus from the salt marsh plant (Sueada maritime) occurring along the velar estuary of southeast coast of India (Indira et al., 2015), Colletotrichum, Fusarium, Phoma and Penicillium isolated from plants (Chow \& Ting, 2015).

The optimization of cultural and environmental condition is an important requirement for the production of L-asparaginase. In this research Taguchi design was employed to try 18 different media for L-asparaginase production in addition to the medium no "19". Many statistical experimental design methods have been employed for optimization bioprocess (Ferreira et al., 2004 and Prasad et al., 2005). These methods have been successfully applied to optimize different process parameters (Vanot et al., 2002 and Dutra et al., 2006). Applications of such designs minimize the error in determining the effect of parameter than the classic time-by-time optimization experiments (Zheng et al., 2008). The significant factors differ, depending on the tested microorganisms. Glucose, $\mathrm{pH}$, aeration and agitation speed were determining factors for L-asparaginase production from Fusarium equiseti (Hosamani \& Kaliwal, 2011) and Aspergillus sp. (Ahmed et al., 2015). Statistical methodologies are generally preferred by several investigators in determining the effect of interacting factors (Sharma \& Satyanarayana, 2006). Hence statistical optimization design for maximization of $\mathrm{L}$-asparaginase production and activity of $A$. sydowii and $F$. oxysporum was carried out using Taguchi design. Our results revealed that A. sydowii and $F$. oxysporum exhibited the highest $\mathrm{L}$-asparaginase activities in the culture filtrate after 5 days incubation. The data also showed that the dried biomasses of both fungal species are matched with L-asparaginase activities. Also the modified medium "19" was the optimum for production of L-asparaginase followed by medium "13" and medium "6". The poorest L-asparaginolytic activity of $A$. sydowii or $F$. oxysporum was recorded in case of medium "3". Addition of relatively higher amount of L-asparagine was found to be suitable for maximum L-asparaginase activity reaching 146 and $143 \mathrm{U} / \mathrm{ml}$ after 5 days of incubation in case of $A$. sydowii and $F$. oxysporum, respectively. Our observation confirmed the data published earlier by Basker \& Renganathan (2009) working with production of L-asparaginase from $A$. terreus MTCC 1782 . Their study revealed that $1.0 \%$ sodium nitrate and $1.2 \% \mathrm{~L}$-asparagine induced considerable L-asparginase activity of $30.53 \mathrm{U} / \mathrm{ml}$ on the fourth day. However, glucose was the preferred carbon source for production of L-asparaginase by Bedaiwy et al. (2016).

From the pervious data the optimum modified Czapek's Dox medium "19" was selected for antileukemic and anti-cancer assays of L-asparaginase produced by $A$. sydowii and $F$. oxysporum. The crude L-asparaginase from both fungi exhibited antileukemic concentrations activities dependent with the concentration required for a $50 \%$ inhibition of viability $\left(\mathrm{IC}_{50}\right)$ of 50.0 and $62.5 \mathrm{U} / \mathrm{ml}$, respectively. It is well known that, the L-asparaginase is very effective anti-leukemic agent and for most patients and probably administered once every two weeks (Graham, 2003 and Oza et al., 2010). The relative selectivity with regard to metabolism of malignant tumor cell forces to look for novel L-asparaginase with little L-glutaminase producing system compared to existing enzymes (Parkasham et al., 2010). L-asparaginase has revolutionized the antileukemic therapy of acute lymphoblastic leukemia (ALL). It is early sustained that L-asparagine depletion extends at least up to the first 30 weeks of therapy (Patil et al., 2011). Performing in vitro anticancer test, our results revealed that the cell death percent of carcinoma cell lines reached between 70 to $80 \%$ after treatment with the crude L-asparaginase of either A. sydowii or Foxysporum, respectively. In this respect, tumor cells especially, lymphatic cells, require huge amounts of L-asparagine to keep up their malignant growth. L-asparaginase, as a drug, exploits this unusually high requirement of L-asparagine because the malignant cells lack L-asparagine. Hence, L-asparagine in the tumor cells forms an essential factor for protein synthesis. Healthy cells, however, not affected, as they are capable of synthesizing L-asparagine with the help of L-asparagine synthetase which is present in sufficient amounts (Narta et al., 2007). 
L-asparaginase arrest cell cycle at "G1" phase in the leukemia murine L5178 cell line (Ueno et al., 1977) and in the MOLT-4 human T-lymphoblastic line (Shimizu et al., 1992). Ammonia produced from L-asparagine hydrolysis diffuse into the cytosol and change the $\mathrm{pH}$ which activate signal transduction pathway associated apoptosis (Ueno et al. 1977 and Shimizu et al., 1992). Moreover, L-asparaginase have anti-carcinogenic effects in animal and cell culture by decreasing the expression of nuclear factor-Kapp- B, suppressing intercellular tumor necrosis factor and potentiating apoptotic signaling in cancerous cells (Story et al., 1993 and Ichikawa et al., 2006). L-asparagine deficiency rapidly impairs the protein synthesis and leads to inhibition of DNA and RNA synthesis and hence an impairment of cellular function resulting in cell death (Narta et al., 2007).

In conclusion, the present study showed that L-asparaginase could be produced from local strains of filamentous fungi. Maximization of enzyme production can be achieved under suitable nutritional and environmental fermentation conditions. More trials are needed to concentrate, purify, lyophilize and preserve this important product to find its way for application in the field of medicine.

\section{References}

Ahmed, M.M.A., Abo Dahab, N.F., Taha, T.M. and Hassan, F.S.M. (2015) Production, purification and characterization of L-asparaginase from marine endophytic Aspergillus sp. ALAA-2000 under submerged and solid state fermentation. J. Microb. Biochem. Technol. 7(3), 165-172.

Altschul, S.F., Madden, T.L., Schaffer, A.A., Zhang, Z., Miller, W. and Lipman, D.J. (1997) Gapped BLAST and PSI-BLAST: A new generation of protein databases search programs. Nucleic Acid Res. 25, 3389-3402.

Archana, J.R. and Raja, P.R. (2014) Production, purification and characterization of L-asparaginase from Aspergillus nidulans by solid state fermentation. European J. Biotechnol. Biosci. 2(4), 51-58.

Baskar, A. and Renganathan, S. (2009) Production of L-aspartaginase from natural substrates by Aspergillus terreus MTCC 1782: Effect of substrate, supplementary nitrogen source and L-asparaginase. Int. J. Chem. Reactor. Eng. 7(1), online

Bedaiwy, M.Y., Awadalla, O.A., Abou-Zeid, A.M. and Hamada, H.T. (2016) Optimal conditions for production of L-asparaginase from Aspergillus tamarii. Egypt. J. Exper. Biol. (Botany), 12(2), 229237.

Booth, C. (1971)"The Genus Fusarium". Commonwealth Mycological Institute, Kew, Surrey, England, pp. 237.

Booth, C. (1977) "Fusarium Laboratory Guide to the Identification of the Major Species". Commonwealth, Surrey, England, pp. 58.

Cachumba, J.J., Antunes, F.A., Peres, G.F., Brumano, L., Santos, J.C. and Da Silva, S.S. (2016) Current applications and different approaches for microbial L-asparaginase production. Brazilian J. Microbiol. 47(1), 77-85

Chow, Y.Y. and Ting, A.S.Y. (2015) Endophytic L-asparaginase- producing fungi from plants associated with anti-cancer properties. J. Adv. Res. 6, 869-876

Clavell, L.A., Gelber, R.D., Cohen, H.J., Hich cockBryans, S., Cassady, J.R., Tarbell, N.J., Blattner, S.R., Tantravahi, R., Leavit, P. and Sallan, S.E. (1986) Four agent induction and intensive assparginase therapy for treatment of childhood acute lymphoblastic leukemia. New Engl. J. Med. 315, 657-663.

Dange, V. and Peshwe, S. (2015) Purification and biochemical characterization of L-asparaginase from Aspergillus niger and evaluation of its antineoplastic activity. Int. J. Sci. Res. 4(2), 564-569.

Dhale, M.A. and Mohan-Kuman, H.P. (2014) A comparative rapid and sensitive method to screen L-asparaginase producing fungi. J. Microbiol. Methods, 102, 66-68.

Dutra, R.L., Maltez, H.F. and Carasek, E. (2006) Development of an online pre-concentration system for zinc determination in biological samples. Talanta, 69, 488-493.

Edward, I.A. (2001) "DNA Technology". $2^{\text {nd }}$ ed., Academic Press, San Diego, California, USA, pp. 348.

El-Naggar, N.F., Derez, S.F., Soliman, H.M., El-Deeb, N.M. and El-wasy, S.M. (2016) Purification, characterization, cytotoxicity and anti-cancer activities of L-asparaginase, anti-colon cancer protein from the newly isolated alkaliphilic $S$. fradiae. Sci. Rep. 6, 32926.

El-Sayed, A.S. (2008) Studies on some anti-tumor producing fungi. Ph. D. Thesis, Faculty of Science, Zagazig University. Egypt, pp. 157. 
ELshafei, A.M. and EL- Ghonemy, D.H. (2015) Screening and media optimization for enhancing L-asparaginase production, an anti-cancer agent, from different filamentous fungi in solid state fermentation. British Biotechnol. J. 9(3), 1-15.

Farag, A.M., Hassan, S.W., Beltagy, E.A. and ElShenawy, M.A. (2015) Optimization of production of anti-tumor L-asparaginase by free and immobilized marine Aspergillus terreus. Egypt. J. Aquat Res. 41, 295-302.

Ferreira, S.I.C., Dos-Santos, W.N.L., Quintella, C.M., Neto, B.B. and Bosque-Sendra, J.M. (2004) Doehlert matrix, a chemo metric tool for analytical chemistry Review Talanta, 63, 1061 -1067.

Graham, M.L. (2003) L -asparaginase a review of clinical studies. Adv. Drug Delivery Rev. 55, 1293-1302.

Gulati, R., Saxena, R.K. and Gupta, R. (1997) A rapid plate assay for screening L-asparaginase producing microorganisms. Lett. Appl. Microbiol. 24, 23-26.

Gupta, N., Dash, S.J. and Basak, U.C. (2009) L-asparaginases from fungi of Bhitarkanika mangrove ecosystem. Asia Pac. J. Mol. Biol. Biotechnol. 17(1), 27-30.

Hansen, M.B., Nielsen, S.E. and Berg, K. (1989) Reexamination and further development of precise and rapid dye methods for measuring cell growth/cell kill. J. Immunol. Methods, 119, 203-210.

Hill, J.M. (1967) L-asparaginase therapy for leukemia and other malignant neoplasms. J. Am. Med. Assoc. 202(9), 882-888.

Hosamani, R. and Kaliwal, B.B. (2011) L-asparaginase anti-tumor agent production by Fusarium equiseti using solid state fermentation. Int. J. Drug Discovery, 3(2), 88-99.

Ichikawa, H., Takada, Y., Shishoda, S., Jayaprakasam, B., Nair, M.G. and Aggarwal, B.B. (2006) Withanolides potentiate apoptosis, inhibit invasion, and abolish osteoclastogensis through suppression of nuclear factor- ${ }_{\mathbf{K}} \mathrm{B}\left(\mathrm{NF}-{ }_{\mathbf{K}} \mathrm{B}\right)$ activation and NF-KB- regulated gene expression. Mol. Cancer Ther. 5(6), 1434-1445.

Imada, A., Igarasi, S., Nakahama, K. and Isono, M. (1973) Asparaginase and glutaminase activities of microorganisms. J. Gen. Microbiol. 76, 85-99.

Indira, K., Jayaprabha, N., Balakrishnan, S., Arulmoorthy, P. and Srinivasan, M. (2015) Production, purification and characterization of extracellular L-asparaginase from salt marsh fungal endophytes. World J. Pharm. Pharm Sci. 4(3), 663-677.
Isaac, G.S. and Abu-Tahon, M.A. (2016) Production of extracellular anti-leukemic enzyme L-asparaginase from Fusarium solani AUMC 8615 grown under solid-state fermentation conditions: Purification and characterization of the free and immobilized enzyme. Egypt. J. Bot. 56, 799-816.

Johnson, L.F., Curl, E.A., Bond, J.H. and Fribourg, H.A. (1959) "Methods for Studying Soil MicroFlora-Plant Disease Relationships". Minneapolis: Burgess Pub. Co., pp. 178.

Keating, M.J., Holme, R., Lerner, S. and Ho, D.H. (1993) L-asparaginase and polyethylene glycol (PEG) asparaginase past, present and future. Leuk Lymphoma, 10, 153-157.

Krasotkina, J., Borisova, A.A., Gevaziev, Y.V. and Sokolov, N. (2004) One-step purification and kinetic properties of the recombinant L-asparaginase from Erwinia carotovora. Biotechnol. Appl. Biochem. 39, 215-221.

Lincoln, L., Niyonzima, F.N. and More, S.S. (2015) Purification and properties of a fungal L-asparaginase from Trichoderma viride Pers: SF Grey. J. Microbiol. Biotechnol. Food Sci. 4(4), 310-316.

Lubkowski, J., Palm, G.J., Gillilan, G.L., Derst, C., Rohm, K.H. and Wlodawer, A. (1996) Crystal structure and amino acid sequence of Wolinela succinogenes L-asparaginase. European J. Biochem. 241, 201-207.

Moubasher, A.H. (1993) "Soil Fungi in Qatar and Other Arab Countries". Scientific and Applied Research Center, University of Qatar, pp. 566.

Nakahama, K., Imada, A., Igarasi, S. and Tubaki, K. (1973) Formation of L-asparaginase by Fusarium species. J. Gen. Microbiol. 75, 269-276.

Narta, U.K., Kanwar, S.S. and Azmi, W. (2007) Pharmacological and clinical evaluation of L-asparaginase in the treatment of leukemia. Clin. Rev. Oncol/Hematol. 61(3), 208-221.

Niharika, Y.C. and Supriya, S. (2014) Production of L-asparaginase by Fusarium oxysporum using submerged fermentation. Int. J. Pharm. Sci. Invention, 3(6), 32-40.

Oliver, R.P. and Schweizer, M. (1999) "Molecular Fungal Biology", Cambridge University Press, pp. 377.

Oza, V.P., Parmar, P.P. and Kumar, S. (2010) Anticancer properties of highly purified L-asparaginase from Withania somnifera L. against acute lymphoblastic 
leukemia. Appl. Biochem. Biotechnol. 160, 18331840 .

Parkasham, R.S., Hymavathi, M., Rao, C.S., Arepalli, S.K., Rao, V., Kennady, P.K., Nasaruddin, K., Vijayakumar, J.B. and Sarma, P.N. (2010) Evaluation of anti-neoplastic activity of extracellular asparaginase produced by isolated Bacillus circulans. Appl. Biochem. Biotechnol. 160, 72-80.

Patil, S., Coutsouvelis, J. and Spencer, A. (2011) Asparaginase in the management of adult acute lymphoblastic leukemia: Is it used appropriately. Cancer Treat. Rev. 37, 202-207.

Prasad, K.K., Mohan, S.V., Rao, R.S., Pati, B.R. and Sarma, P.N. (2005) Laccase production by Pleurotus ostreatus 1804 optimization of submerged culture conditions by Taguchi DOE methodology. $J$. Biochem. Eng. 24, 17-26.

Radhika, T. and Girisham, S. (2012) Nutritional factors effecting the production of L-asparaginase by the Furarium sp. Afr. J. Biotechnol. 11(15), 3692-3696.

Raper, K.B. and Fennell, D.I. (1965) "The Genus Aspergillus", The Williams and Wilkins Company, Baltimore, pp. 686.

Ruma, K., George,T.K., Aswani, P. and Jisha, M.S. (2017) Production and optimization of extracellular L-asparaginase by Fusarium solani isolated from Withania sominifera. J. Biol. Act. Prod. Nature, 7(2), 81-88.

Sanjotha, G. and Manawadi, S.I. (2017) Isolation, screening, optimization and production of anti-tumor L-asparaginase by fungi from Karwar coastal region. Res. J. Recent Sci. 6(3), 1-7.

Sharma, D.C. and Satyanarayana, T. (2006) A marked enhancement in the production of a highly alkaline and thermostable pectinase by Bacilluspumilus desr I in submerged fermentation by using statistical methods. Bioresour Technol. 97, 727:733

Shimizu, T., Kubota, M. and Adachi, S., Sano, H., Kasai, Y., Hashimoto, H., Akiyama,Y. and Mikawa, H. (1992) Pre-treatment of a human T-lyphoblastoid cell line with L-asparaginase reduces topsideinduce DNA strand breakage and cytotoxicity. Int. J. Cancer, 50, 644-648.

Shrivastava, A., Khan, A.A., Khurshid, M., Kalam, M.A., Jain, S.K. and Singhal, P.K. (2016) Recent developments in L-asparaginase discovery and its potential as anticancer agent. Clin. Rev. Oncol./ Hematol. 100, 1-10.
Skehan, P., Storeng, R., Scudiero, D., Monks, A. and McMahon, J. (1990) New colorimeteric cytotoxicity assay for anti-cancer drug screening. J. National Cancer Inst. 82,1107-1112.

Story, M.D., Voehring, D.W., Stephens, L.C. and Mern, R.E. (1993) L-asparaginase kills lymphoma by apoptosis. Cancer Chemother Pharmacol. 32, 129133.

Tamura, K., Peterson, D., Peterson, N., Stecher, G., Nei, M. and Kumar, S. (2011) MEGA 5. Mol. Biol. Evol. 28, 2731-2739.

Ueno,T., Ontawa, K., Mitusi, K., Kodera, Y., Hiroto, M., Matsushima, A., Inada, Y. and Nishimura, H. (1977) Cell cycle arrest and apoptosis of leukemia cells induced by L-asparaginase. Leukemia, 11, 18581861

Vanot, G., Val'erie, D., Guilhem, M.C., Phan-Yan-Luu, R. and Comeau, L.C. (2002) Maximizing production of Penicillium cyclopium partial acylglycerol lipase. Appl. Microbiol. Biotechnol. 60, 417-419.

Verma, N.K., Kumar, G. and Kaur, A. (2007) L-asparaginase: A promising chemotherapeutic agent. Clin. Rev. Biotechnol. 27, 45-62.

Vidya, J., Sajitha, S., Ushasree, M.V., Binod, 1.P. and Pandey, A. (2017) Therapeutic enzymes: L-asparaginases. Curr. Dev. Biotechnol. Bioeng. 249-265.

White, T.J., Bruns, T., Lee, S. and Taylor, J. (1990) In: "Amplification and Direct Sequencing of Fungal Ribosomal RNA Genes for Phylogenetic", M.A. Innis, D.H. Gelfand, pp. 258.

Wilson, K. and Walker, J. (1995) "Principles and Techniques of Practical Biochemistry". $4^{\text {th }}$ ed., Cambridge, pp. 586.

Zheng, Z.M., Hu, Q.L., Hao, J., Xu, F., Guo, N.N., Sun, Y. and Liu, D.H. (2008) Statistical optimization of culture conditions for 1,3 propanediol by Klebsiella pneumoniae $\mathrm{AC}$ is via central composite design. Bioresour. Technol. 99, 1052-1056.

Zuo, S., Zhang, T., Jiang, B. and Mu, W. (2014). Recent research progress on microbial L-asparaginases. Appl. Microbiol. Biotechnol. 99(3), 1069-1079.

(Received 18/2/2018 accepted 3 / 5 /2018) 


\section{الانتاجية المثلي لاتزيم ال- اسباراجينيز من بعض الفطريات الخيطية ولها خواص علاجية

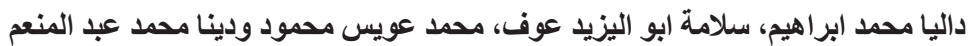
قسم النبات و الميكروبيولوجى ـ كلية العلوم- جامعة القاهرة ـ الجيزة ـ القاهره ـ مصرد.

في هذه الدراسة تم عزل مائة و ثلاثة و اربعون عزلة من الفطريات من مو اقع مختلفة تتمثل في (14 عزلة التابلة

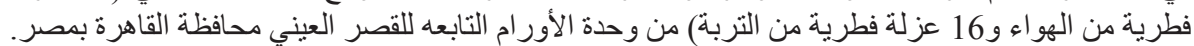

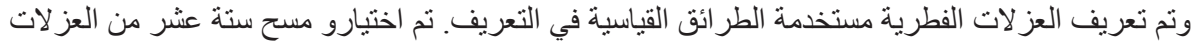

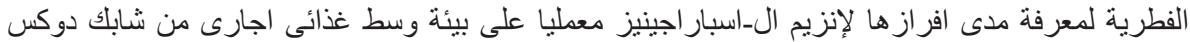
تحتوي على ال- اسبار اجين كمصدر للنيتروجين في وجود كاشف لأنين فينول الأحمر .

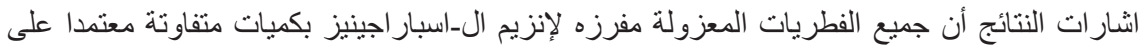

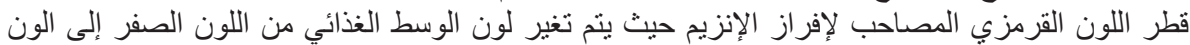

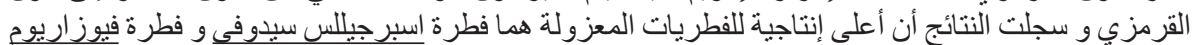
اوكسبيبورم.

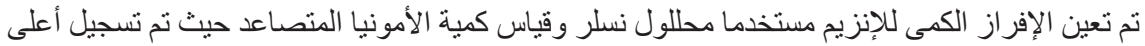

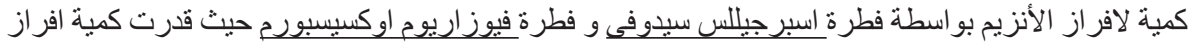

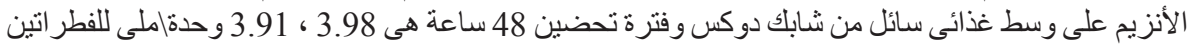

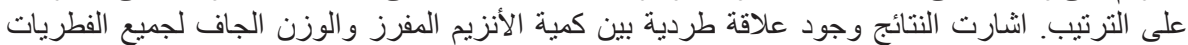

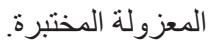

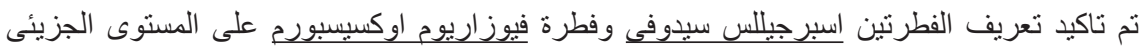

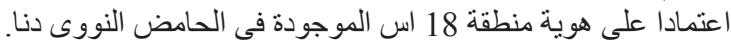

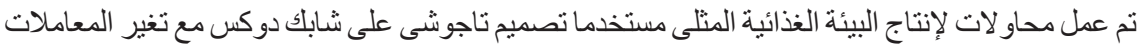

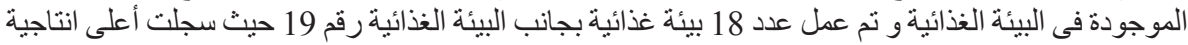

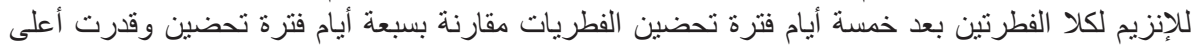
إنتاجية للأنزيم الخام هى 146 و 143 وحدة/ملى في الرشيح على التريب.

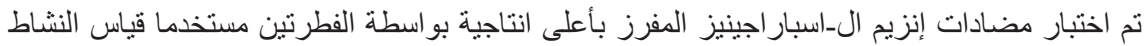

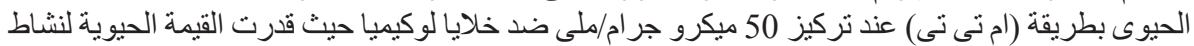
عند 50 و62,5 وحدة انزيج|ملى للفطرتين على الترتيب.

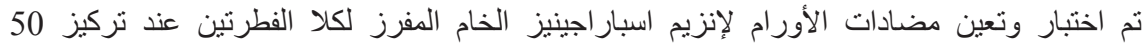

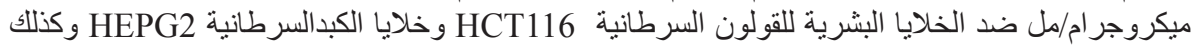

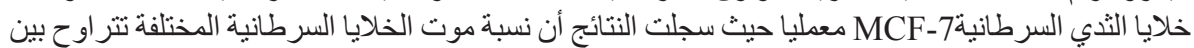
70 إلى 80\% بإستخدام الأنزيم الدفرز الخام لكلا الفطرتين. 